\section{Contribution of congenital disorders to under-5 mortality}

To the Editor: The article "Where do children die and what are the causes?', which appeared in the April 2016 issue of the SAMJ, ${ }^{[1]}$ provides an overview of the causes of death in under- 5 children in the Metro West geographical service area of the Western Cape for 2011. It highlights the proportion of under-5 deaths from congenital abnormalities (obvious structural abnormalities), which are particularly prevalent in early neonatal mortality - a close third (9.6\%) of in-hospital deaths after hypoxia (10.0\%) and immaturity (40.6\%) according to the Perinatal Problem Identification Programme (PPIP) data. ${ }^{[1]}$ In the Local Mortality Surveillance System in-hospital data, congenital abnormalities are ranked as the second (13.5\%) cause of early neonatal death after prematurity $(35.8 \%){ }^{[1]}$

Although already prominent as a cause of death, congenital disorders (CDs) may collectively contribute to a greater proportion of child deaths than reported. In the study, congenital abnormalities relate to chapter XVII: Congenital malformations, deformities and chromosomal abnormalities in the International Classification of Diseases (ICD-10) and are aggregated to the Burden of Disease list of causes. ${ }^{[1-3]}$ Limited to developmental structural abnormalities only, this excludes a significant portion of CDs found elsewhere in the ICD10 system (e.g. congenital syphilis A50; haemophilia D66 - 68; oculocutaneous albinism E70.310). ${ }^{[3]}$ This ICD-10 coding fragmentation has exacerbated global confusion around terminology related to CDs. ${ }^{[4]}$ In 2006, international agreement was reached on the synonymous use of the terms CDs and birth defects, defined as abnormalities of structure or function, including metabolism, present from birth and manifesting at birth or later in life. ${ }^{[5]}$ However, use of inequivalent terms, such as congenital abnormality, continues. Consequently, data for subsets of CDs are often interpreted as the totality of CDs when it is not the case. If single-gene disorders, accounting for $30.0 \%$ of CDs (B Modell - personal communication, 2016), were pooled with congenital abnormalities in the study by Reid et al. ${ }^{[1]}$ a greater proportion of under- 5 deaths may be attributed to CDs.

CDs are also significantly underestimated, as many remain undiagnosed or are misdiagnosed, with the incorrect cause of death due to the lack of trained clinicians, ${ }^{[6-8]}$ as acknowledged by the Child Healthcare Problem Identification Programme. ${ }^{[4,9]}$ Undiagnosed CDs may be the underlying cause of death in a number of cases assigned to other causes (including 'ill-defined') or comorbidity in the study, as infants born with CDs, such as congenital heart defects, may be more susceptible to infection.

Honein et al. ${ }^{[10]}$ reported that $\mathrm{CDs}$ are more than five times as likely to occur among very preterm infants (24 - 31 weeks) compared with term infants (37 - 41 weeks), resulting in $16.0 \%$ of preterm infants having a CD. A significant portion of deaths assigned to 'prematurity' in early neonatal deaths in the study may therefore be undiagnosed CDs, which are predisposed to preterm birth.

The relative frequency of CDs should be noted and investigated in light of the abovementioned factors contributing to their underreporting, particularly as the majority of $\mathrm{CD}$-related deaths occur during the first 5 years of life. As the proportion of deaths from CDs increases along with epidemiological transition - seen in the dramatic decrease in HIV-related deaths - the challenge of CDs will continue. ${ }^{[11]}$ Possible areas for further study include comparison with other provincial populations, analyses of preventable CDs (e.g. fetal alcohol spectrum disorder) and prenatal diagnosis of serious CDs.

\section{H L Malherbe, C Aldous}

School of Clinical Medicine, College of Health Sciences, University of KwaZulu-Natal, Durban, South Africa

helen@hmconsult.co.za

\section{A L Christianson}

Wits Centre for Ethics (WiCE), Faculty of Humanities, University of the Witwatersrand, Johannesburg, South Africa

\section{Woods}

Division of Neonatal Medicine, School of Child and Adolescent Health, Faculty of Health Sciences, University of Cape Town, South Africa

\footnotetext{
1. Reid AE, Hendricks MK, Groenewald P, Bradshaw D. Where do children die and what are the causes? Under-5 deaths in the Metro West geographical service area of the Western Cape, South Africa, Under-5 deaths in the Metro West geographical service area of the Western
2011. S Afr Med J 2016;106(4):359-364. DOI:10.7196/SAMJ.2016.v106i4.10521

2. Pillay-Van Wyk V, Laubscher R, Msemburi W, et al. Second South African National Burden of Disease . Pillay-Van Wyk V, Laubscher R, Msemburi W, et al. Second South African National Burden of Disease
Study: Data Cleaning, Validation and South African National Burden of Disease List. Cape Town: Study: Data Cleaning, Validation and South African National Burden of Disease List.
Burden of Disease Research Unit, South African Medical Research Council, 2014:1-51.

Burden of Disease Research Unit, South African Medical Research Council, 2014:1-51.
3. World Health Organization. International Statistical Classification of Diseases and Related Health World Health Organization. International Statistical Classification of Diseases and Related Health
Problems. 10th revision. Geneva: WHO, 1992. http://apps.who.int/classifications/icd 10/browse/2015 en (accessed 1 June 2016).

4. Malherbe H, Aldous C, Woods D, Christianson A. The contribution of congenital disorders to child mortality in South Africa. In: Padarath A, King J, Mackie E, Casciola J, eds. South African Health Review. Durban: Health Systems Trust, 2016:137-152.

5. World Health Organization. Management of Birth Defects and Haemoglobin Disorders. Report of a Join WHO/March of Dimes Meeting. Geneva, Switzerland, 17 - 19 May 2006. Geneva: WHO, 2006:1-27.

6. World Health Organization. Prevention and Management of Genetic Disorders and Birth Defects in Developing Countries. Report of a joint WHO/WAOPBD meeting, The Hague, 5 - 7 January 1999. Geneva: WHO, 1999. http://www.who.int/genomics/publications/reports/en/ (accessed 27 February 2016).

7. Christianson A, Modell B. Medical genetics in developing countries. Ann Rev Genomics Hum Genet 2004;5:219-265. DOI:10.1146/annurev.genom.5.061903.175935

8. Christianson A, Howson CP, Modell B. March of Dimes: Global Report on Birth Defects, the Hidden . Christianson A, Howson CP, Modell B. March of Dimes: Global Report on
Toll of Dying and Disabled Children. White Plains: March of Dimes, 2006.

9. Patrick ME, Stephen CR. Saving children: 2005. A survey of child healthcare in South Africa. Child
. Patrick ME, Stephen CR. Saving children: 2005. A survey of child healthcare in South Africa. Child
Healthcare Problem Identification Programme and Medical Research Council, 2005. http://www. Healthcare Problem Identification Programme and Medical Research Council, 2005.
childpip.org.za/documents/report_saving_children_2005.pdf (accessed 23 March 2016).

10. Honein MA, Kirby RS, Meyer RE, et al. The association between major birth defects and preterm birth Matern Child Health J 2009;13(2):164-175. DOI:10.1007/s10995-008-0348-y

11. Malherbe $\mathrm{H}$, Christianson A, Aldous C. Need for services for the care and prevention of congenital disorders in South Africa as the country's epidemiological transition evolves. S Afr Med J
} 2015;105(3):186-188. DOI:10.7196/SAMJ.9136

S Afr Med J 2016;106(8):745. DOI:10.7196/SAMJ.2016.v106i8.11129 